\title{
Engaging Faculty in Professional Development: Lessons From Bangladesh
}

\author{
Mohammad Omar Shiddike ${ }^{1}$ \& Asif Ali Rahman ${ }^{1}$ \\ ${ }^{1}$ Faculty of Education, University of Regina, Canada \\ Correspondence: Mohammad Omar Shiddike, Ph.D. Candidate, Faculty of Education, University of Regina, \\ Regina, SK, S4S0A2, Canada. Tel: 1-(306)-580-1030. E-mail: shiddikm@uregina.ca
}

Received: August 10, 2019

Accepted: September 20, 2019 Online Published: September 23, 2019

doi:10.5539/jedp.v9n2p124

URL: http://doi.org/10.5539/jedp.v9n2p124

\begin{abstract}
Engagement can be defined as participation, involvement, and commitment (Harper \& Quaye, 2015). This paper explains faculty engagement in professional development. Faculty engagement in professional development can be defined as faculty participation and involvement in formal and informal learning activities. These formal and informal activities focus on professionalism that might include exercises leading to the development of knowledge, skills, abilities, values, and self-awareness. Some examples of these formal and informal learning activities are classroom teaching, curriculum and instruction development, training, consulting, faculty/student interactions, workshops/conferences, and academic publications etc. Faculty engagement in professional development incorporates the total sum of formal and informal learning or continuous learning throughout one's career (Broad \& Evans, 2006; Capps, Crawford, \& Constas, 2012). Since professional development includes faculty engagement, the paper explores how university faculty professionally develop themselves through engagement.
\end{abstract}

Keywords: faculty engagement, faculty professional development, training and development, Bangladesh higher education, faculty development, Bangladesh higher institution etc.

\section{Introduction}

Engagement can be defined as participation, involvement, and commitment (Harper \& Quaye, 2015). This paper explains faculty engagement in professional development. Faculty engagement in professional development can be defined as faculty participation and involvement in formal and informal learning activities. These formal and informal activities focus on professionalism that might include exercises leading to the development of knowledge, skills, abilities, values, and self-awareness. Some examples of these formal and informal learning activities are classroom teaching, curriculum and instruction development, training, consulting, faculty/student interactions, workshops/conferences, and academic publications etc. Faculty engagement in professional development incorporates the total sum of formal and informal learning or continuous learning throughout one's career (Broad \& Evans, 2006; Capps et al., 2012). Since professional development includes faculty engagement, the paper explores how university faculty professionally develop themselves through engagement.

\subsection{Evolution of Education in Bangladesh}

The word "Bangladesh" is a combination of two words: "Bangla" meaning Bangla language and "Desh" meaning country. In short, a country where Bangla language is spoken. Bangladesh became independent in 1971. Its total land area is 147,570 square kilometers. The country is located in South Asia, and is bounded by India to the northwest, Myanmar to the southeast, and the Bay of Bengal to the south. It is the eighth largest country of the world in terms of population. Bangladesh is one of the most densely populated countries of the world.

At the time of its independence, Bangladesh had only four universities: The University of Dhaka, Jahangirnagar University, The University of Chittagong, and The University of Rajshahi (Islam, 2014). At present, Bangladesh has 135 private and public sector universities. These universities fall under the three categories of higher education: The National University (NU) and its affiliated colleges and universities, Madrasha (Islamic Studies and Arabic) education, and the Technical and Vocational Education and Training (TVET) (Bangladesh Bureau of Educational Information and Statistics (BANBEIS), 2017).

Education is considered to be the most important resource in Bangladesh (Hassan, 2016; Hossain \& Khan, 2014). Therefore, a focus on education is integral to the development of Bangladesh. After independence, the government 
of Bangladesh took various steps to modernize the education system. Some of those steps were to establish various education commissions and committees and make it accessible to general public. Previously, education was considered a luxury which excluded ordinary people (Monem \& Baniamin, 2010; M. M. Rahman, 2013).

Consequently, a lack of access to the higher education led to various problems for the students of public sector universities. This has been one of the biggest challenges Bangladesh higher education students has faced over the years (Sarker, Rana, \& Zitu, 2013). Some of the other challenges faced by higher education include faculty recruitment, professional development, the use of technology in classrooms, corruption, nepotism, and political influences, among others (Ahmmed, 2013; Hossain \& Khan, 2014; Monem \& Baniamin, 2010). These challenges have been worsened by the strong influence of government on the country's higher education regulatory body, the University Grants Commission (UGC). Since UGC has the authority to take action against any higher education irregularities, there must be strong policies, programs, and practices that not only act as guidelines but also enforce quality education (University Grants Commission (UGC), 2018).

Moreover, the education system of any country is a fundamental determinant of economic development (Hanushek, 2016; Siegfried, Sanderson, \& McHenry, 2007). In Bangladesh, students must complete 12 years of schooling before they are admitted to universities. Hassan (2016) noted that there are four types of universities in Bangladesh, which are: National university, public universities, private universities, and distance education universities, e.g., Bangladesh Open University (BOU). Students may choose which type of higher educational institution to join depending on the program they want to pursue.

Faculty recruitment in Bangladesh undergoes the following process. First, the university faculty (teaching in university affiliated colleges) are recruited through the Bangladesh Civil Service (BCS) exam. Second, the Ministry of Education posts, transfers, and promotes faculty. From the above, it can also be inferred that while higher education has undergone an extensive transformation in Bangladesh, there are still concerns regarding the development and accessibility of education for all.

\subsection{Overview of Higher Education in Bangladesh}

In Bangladesh, children join universities after 12 years of schooling. Universities in Bangladesh start with Bachelor degrees (Pass and Honours). There are two streams for higher education. These two streams are: General/Technical Education, and Madrasha Education (BANBEIS, 2017). Higher education in Bangladesh is explained in detail in Figure 1.

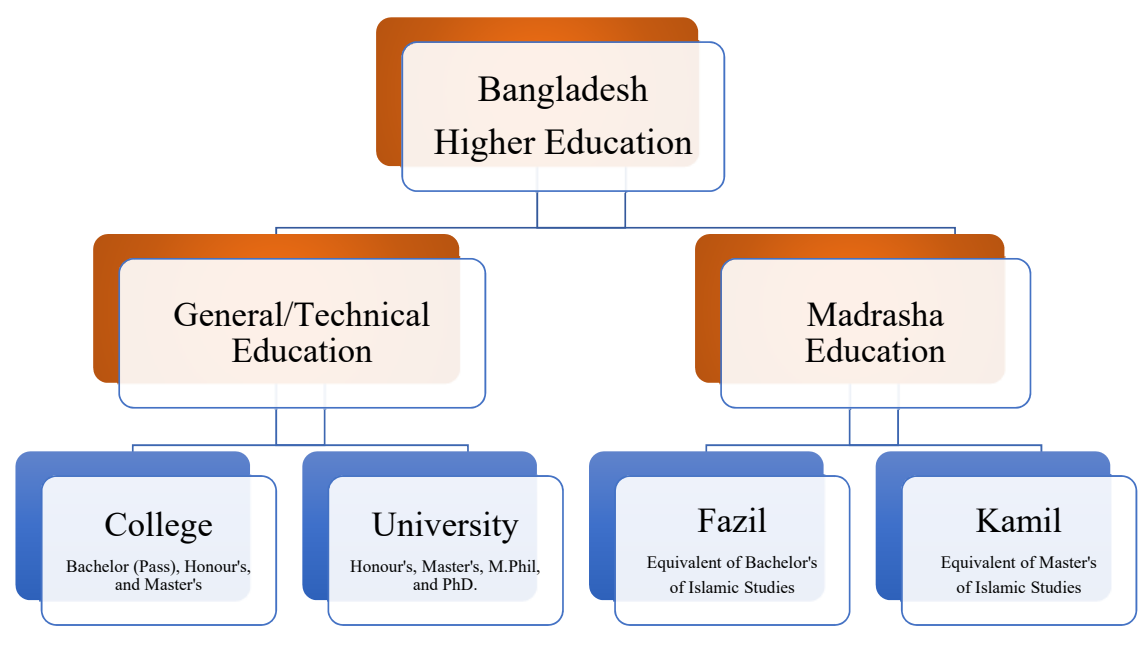

Figure 1. Higher Education in Bangladesh

Bangladesh is witnessing an exponential growth in the establishment of new institutions and universities. There are many reasons for that. One of the reasons is the government's increased interest in higher education. Another reason is that private sector has entered the domain of higher education. According to BANBEIS (2017), higher education institutions have been steadily increasing. Table 1 shows the number of colleges (public and private) in 2017. 
Table 1. Number of Colleges (Private and Public) in 2017

\begin{tabular}{lllll}
\hline College & Degree (Pass) & Honours & Masters & Total \\
\hline Private & 1058 & 460 & 61 & 1579 \\
Public & 68 & 108 & 107 & 328 \\
Total & 1126 & 568 & 168 & 1862 \\
\hline
\end{tabular}

Source: Adapted from BANBEIS, (2017, p. 103)

As shown in Table 1, Bangladesh has a total of 1,862 private and public sector colleges (1579 private and 328 public, including 68 medical colleges and 15 dental colleges). Degree (Pass) colleges offer programs such as Bachelor of Science, Bachelor of Arts, Bachelor of Business (Commerce), two-years Bachelor of Social Science, and two-years Master's degrees. Honours and Master's colleges offer programs such as Bachelor of Science, Bachelor of Arts, Bachelor of Business (Commerce) four-years Honour's degree and one-year Master's degree.

Table 2. Number of Universities (Private and Public), 2017

\begin{tabular}{lc}
\hline Types of University & Number of Universities \\
\hline Private (Privately Funded) & 95 \\
Public (Government Funded) & 40 \\
Total & 135 \\
\hline
\end{tabular}

Source: BANBEIS (2017, p. 108).

Table 2 indicates that Bangladesh has a total of 135 universities funded and managed by private and public sector authorities. Adult students can take Honour's, Master's, M.Phil., and PhD degrees in fields like science, arts, business, and engineering, and technical and technology courses in these universities (95 private and 40 public, including Technical and Vocational Education and Training (TVET) institutions). According to figure 1, Bangladesh also has another category of higher educational institution, which is Madrasha (Islamic Studies). These educational institutions are shown in Table 3.

Table 3. Numbers of Madrashas (Private and Public), 2017

\begin{tabular}{llll}
\hline Types of Madrasha & Fazil (Bachelor's) & Kamil (Master's) & Total \\
\hline Private & 1,087 & 231 & 1,318 \\
Public & 0 & 3 & 3 \\
Total & 1,087 & 234 & 1,321 \\
\hline
\end{tabular}

Source: BANBEIS (2017, p. 184).

Table 3 shows Bangladesh has a total of 1,321 Madrashas. There are no publicly funded institutions at the Fazil (Bachelor's degree) level. There are 231 privately funded institutions in the country at the Kamil (Master's degree) level but only three institutions are funded by the government. This reflects the government's lack of approval, commitment, and satisfaction to propagate the Madrasha education but at the same time, a strong contentment and approval of the Islamic institutions at the social level. It highlights a conflict between social and government agendas or maybe a lack of understanding the public sentiments by the government (Islam, 2014).

From the above Tables $(1,2$, and 3), it can be seen that the total number of higher educational institutions in Bangladesh is 3,183. According to BANBEIS (2017), this number of educational institutions is reflected in the demand for growth in higher education. Higher educational institutions provide teaching and academic research that offer undergraduate, graduate, and doctoral degrees, and while public universities can be either research- or teaching-oriented, private universities are mostly teaching-oriented.

However, quality education is an important and primary consideration of higher education all across the world, and it is important that the quality is not static and that it changes with changing environments and advancements in 
technology for it to be dynamic (Monem \& Baniamin, 2010). Just like other countries, offering quality education in Bangladesh is critical for the development of the country and its workforce.

The government also needs to play its role in the development of country through higher education. The government can design policies in such a way that they can lead to quality educational outcomes. SABER (2017) noted six policy dimensions of successful higher education systems: "(1) a strong vision for tertiary education, (2) a clear regulatory framework, (3) modern governance and university autonomy, (4) financing that promotes performance and equity, (5) independent quality assurance, and (6) relevance to the country's social and economic needs" (p. 2). A country can establish proper educational system through the above mentioned six policy dimensions.

The issue of quality within the education system is a primary concern for Bangladesh. Among other educational developments in the country, a rapidly growing educational sector is the main concern. According to SABER, (2017), the number of students has increased from 1.6 million to 2.84 million in just five years (2010 to 2015). This, coupled with an increase in universities has necessitated an examination of how the country's higher education expansion or development has met or continues to meet quality assurance standards. Generally, the relevant aspects in regard to quality assurance are tied to admission access policies, the presence of equal opportunities and credit accumulation, programme design, course overview, resource allocation for courses, research student supervision, assessments and degrees, academic staff, accreditations, and teaching and innovation etc. (Monem \& Baniamin, 2010). These quality aspects are a challenge for policy-makers to ensure not only their implementation but also their sustenance. Higher education survival and relevance in Bangladesh has become highly dependent on them.

Given the above, certain policy dimensions can be used to evaluate a country's education system to determine whether or not the education system is quality-assured (A. A. Rahman \& Shiddike, 2019). SABER (2017) observed that four score rankings can be utilized to benchmark the policy dimensions of countries which are: latent, emerging, established, and advanced. According to the SABER (2017) report, the following are the scores for the policy dimensions in Bangladesh. For the policy dimension of vision for higher education, the overall score for the country was "emerging", and for the policy regulatory framework, the overall score was "established". For the policy dimension of governance of systems and institutions, the overall score was "emerging", and for the policy dimension of financing, the overall score was also "emerging". For the policy dimension of quality assurance, the overall score was "emerging", and for the policy dimension of relevance to social and economic needs, the overall score was "established". In essence, the variations in the policy scores paint a picture of an education system that is facing some challenges, particularly in terms of quality and in the design of the system, even as it continues to adjust to changes in the educational environment and advancements in technology (M. M. Rahman, 2013).

However, it should be noted that various scores highlighted in SABER (2017) require a revision. For example, the score for the policy dimension of vision for higher education is "emerging". Considering that the government of Bangladesh has a tendency of authoritarian policy making practices, it is logical to assume that the government may not offer much room to open discussions regarding the future vision of higher education in the country. Therefore, the score for the policy dimension of vision for higher education might be "latent". There may be a need for the government to be more flexible to bring the score to "emerging" or "established". Similarly, SABER (2017) argues that the score for the policy dimension of relevance to social and economic needs is "established". If the score for the policy dimension of relevance to social and economic needs is "established", then why is Bangladesh not a developed country. Bangladesh still seems to be struggling with its education system because of its multi-pronged (different systems of education existing side-by side in one country causing various social and quality problems) approach to education and a lack of focus. It can be argued that the score for the policy dimension of relevance to social and economic needs may still be "emerging". The so-called "established" relevance to social and economic needs may be in need of a revision or a complete restructuring to put the education system in par with the international standards.

\subsection{Overview of Faculty and Students in Higher Education in Bangladesh}

The number of faculty and students in higher education is increasing every year in Bangladesh. According to BANBEIS (2017), Bangladesh has 3,183 colleges, universities, and Madrashas. However, Bangladesh still needs more institutions to meet the needs of its population. Table 4 shows the number of faculty and students in higher education as of 2017. 
Table 4. Faculty and Students in Higher Education, 2017

\begin{tabular}{|c|c|c|c|c|c|c|}
\hline \multirow{2}{*}{ Higher Ed. Institutions } & \multicolumn{2}{|l|}{ Faculty } & \multirow{2}{*}{ No. of Faculty } & \multicolumn{2}{|l|}{ Students } & \multirow{2}{*}{ No. of Students } \\
\hline & Private & Public & & Private & Public & \\
\hline Colleges & 64,156 & 13,780 & 77,936 & $1,881,106$ & $1,405,030$ & $3,286,136$ \\
\hline Universities & 15,400 & 13,168 & 28,568 & 337,238 & 519,488 & 856,726 \\
\hline Madrashas & 24,035 & 67 & 24,102 & 889,647 & 00 & 889,647 \\
\hline Total & 103,591 & 27,015 & 130,606 & $3,107,991$ & $1,924,518$ & $5,032,509$ \\
\hline
\end{tabular}

Source: Adapted from BANBEIS (2017, pp. 106, 146, 187).

Table 4 shows that a total of 130,606 faculty and 5,032,509 students were enrolled in higher educational institutions in 2017 (BANBEIS, 2017). Moreover, the number of students enrolling in higher education institutions is increasing every year. Therefore, the country requires to recruit more faculty members and take initiative to establish institutions to professionally develop and train a knowledgeable and capable faculty. Shuva and Taisir (2016) also noted that faculty needs to be professionally trained since it plays an important role in producing employable graduates.

Faculty engagement in higher education can be understood in terms of strong leadership, accountability, autonomy, a sense of control over one's academic career, and opportunities for development (Barman \& Ray, 2011). As such, universities are tasked with devising strategies that will promote the factors mentioned above with the aim of building long-term faculty engagement for better outcomes for the institution as well as the faculty members themselves. In fact, just as is the case with other forms of employee engagement, faculty engagement hinges on the manifestation of a high degree of commitment and involvement in the profession.

Faculty engagement also refers to the engagement of faculty in professional activities and professional development. In effect, professional development can help higher learning institutions in specific outcomes such as quality improvement and quality assurance. It has been stated that world-class universities rely on faculty professional development activities (Koellner \& Jacobs, 2015). The issue then is to determine whether or not the engagement of faculty in professional development in Bangladesh is of a desirable standard and that processes, programs, and practices are available for faculty engagement and professional development. In a sense, faculty professional development occurs through increased teaching experience and an ongoing evaluation and examination of their professional and academic activities (Ahmed \& Iqbal, 2018).

\subsection{Faculty Engagement in Professional Development in Bangladesh}

The current scenario of faculty engagement in professional development is not encouraging. There are concerns that faculty has inadequate latest teaching techniques, knowledge, and experience in higher education sector (Hossain \& Khan, 2014). Although the government and a few foreign organizations offer and monitor faculty development projects such as professional development programs and quality assurance endeavours, these efforts remain minimal in the overall bigger educational landscape of the country.

Some of these projects include the Higher Education Quality Enhancement Project (HEQEP). HEQEP is responsible to implement quality standards in higher education. Since 2010, the HEQEP has offered enhancement programs for developing and improving teaching strategies (Mahmud, Mozumder, Shahana, \& Islam, 2018). HEQEP has also introduced two more projects to promote the quality of higher education in Bangladesh. For example, the Bangladesh Research and Educational Network (BdREN), and a quality assurance system for Higher Education Institutions (HEIs). Under the HEIs project, all universities will have an Institutional Quality Assurance Cell (IQAC) with the collaboration of University Grants Commission (UGC). As a result of the HEQEP and the HEIs, every institution is expected to have an acceptable institutional quality assurance cell (Akareem \& Hossain, 2016; Ashraf, Ibrahim, \& Joarder, 2009; Lamagna, 2006).

The Centre of Excellence in Teaching and Learning (CoETL) at the University of Dhaka and the Centre of Excellence Teaching and Learning (CETL) at the British Council offer faculty development and leadership programs. Although a few private universities have also taken a more active role in faculty professional development in recent years, the overall situation of the faculty professional development still remains bleak since private universities form a small portion of the overall number of higher education faculty (Ashraf, Osman, \& Ratan, 2016; Behari-Leak, 2017). Due to the lack of professional development, a large number of faculty are unable to meet the global teaching standards (Ahmed \& Iqbal, 2018; Barman \& Ray, 2011; Behari-Leak, 2017; 
Shuva \& Taisir, 2016).

Sarkar, Rana, and Zitu (2013) stated that: "Quality higher education should not be the slogan only. It should be the commitment and willingness of the government and all concerned" (p. 159). Since higher education faculty is the main resource for human resource development in any country whether it is the university teaching, corporate training or organizational consulting, higher education faculty has to be trained professionally to meet the future human resource needs of Bangladesh. According to BENBEIS (2017), there are 877 teaching and professional development institutions for elementary and high school teachers in Bangladesh. Unfortunately, though, there are no formal institutions for the professional development of higher education faculty. Therefore, higher education faculty engages in partisan politics and other non-productive activities bringing the educational standards down. There is a need for the government to recognize its responsibility in developing the higher education sector and highlight the significance of a modern higher education system in the country. 7692512

\section{Key Issues: Faculty Engagement in Professional Development}

The engagement of faculty in professional development is essential for a healthy higher education system (Barman \& Ray, 2011). Faculty engagement directly influences students' engagement, and helps students to engage in educationally purposeful activities (Barman \& Ray, 2011; Carini, Kuh, \& Kleint, 2006; Kuh, 2009). The activity of teaching involves a level of demand for social engagement which is devoted to establishing strong relationships, which can be rare in other professions (Pianta, Hamre, \& Allen, 2012; Roorda, Koomen, Spilt, \& Oort, 2011). This demand for social engagement can only be inculcated in the students through well-informed, knowledgeable, and a conscientious faculty. Focusing on faculty's professional development is one way of ensuring that. The key issues in faculty engagement in professional development are discussed below:

\subsection{Effective Teaching Strategy}

One of the problems that Bangladesh faces is a lack of professional knowledge of faculty It can be stated as arising from factors such as syllabi and curricula not meeting modern international standards and inadequate expansion of practical education, among others (Ashraf et al., 2016; Hossain \& Khan, 2014). Modernization of curricula and syllabi in the light of new knowledge is one of the essential tasks of any education system (Islam, 2008). In Bangladesh, modernization of curricula and syllabi has been examined by various committees and commissions over the years, yet the country still lacks an effective strategy. For instance, there has been movement from the colonial teaching strategy of memorizing, as established by the Qudrat-E-Khoda Commission of 1974 to the Kabir Chowdhury Commission of 2009, which recommended that the provision of sufficient training resources for faculty is essential among other things (Hossain \& Khan 2014). These problems could be examined and understood from the perspectives of pedagogy versus andragogy.

The major difference between pedagogy and andragogy is that the learner is dependent upon the instructor for all learning in the former, while the learner is self-directed in the later (Kapur, 2015; Kelly, 2017). Given the issue of effective teaching strategy, the problems of the Bangladesh education system, particularly relating to faculty engagement in professional development, could be addressed through the use of andragogy rather than pedagogy (Islam, 2014). According to andragogy, adult students are mature and have moved from dependence to self-direction, their growing experience can serve as a source for learning and they are ready to embrace the challenges of the real world (Merriam, 2008). The government of Bangladesh can, therefore, support the higher education sector in developing systems that aid andragogy-oriented teaching strategies (Merriam, 2001; Nelson, 2014; Trotter, 2006).

\subsection{Academic Research, Innovations, and Publications}

Academic research, innovations, and publications are key aspects of educational development (Beine, Docquier, \& Rapoport, 2008). In Bangladesh, academic research, innovations, and publications can be promoted through academic research, the right government priorities and an increase in the annual education budget (Ahmed \& Iqbal, 2018). Ahmed and Iqbal (2018) noted that Bangladesh lacks institutional capacities that can aid in creating a hub of innovation, mainly because there is a gap between the private sector and the higher education institutions. At the same time, the universities also lack research funding and a will to invest time, money, and effort in publications (Sarker \& Hossain, 2016).

Faculty engagement in professional development can be realized through the development of academic research, innovation centers, and an infrastructure to publish (Ahmed \& Iqbal, 2018; Shuva \& Taisir, 2016). Therefore, the government needs to develop proper higher education policies and infrastructure to facilitate academic research, innovation, and publications to ensure quality and an international relevance. 


\subsection{Research Funds, Grants, and Scholarships}

There is a lack of research funds, grants, and scholarships. The main reason of the scarcity of research funds, grants, and scholarships is that the annual education budget in Bangladesh is only 1\% (Ahmed \& Iqbal, 2018). The absence of research funds, grants, and scholarships can cause be detrimental for faculty engagement in professional development. Some of the issues related to insufficient financial support for faculty are described below: (1) Faculty cannot develop itself professionally in the absence of a proper financial support, (2) There is a lack of financial support for the faculty because of the non-existent university-industry linkages, and (3) A lack of research funds, grants, and scholarship may lead to a lack of faculty professional development, which may in turn lead to low levels of faculty engagement ultimately resulting in a lack of the required knowledge and low teaching quality (Mazumder, 2014; Mohsin \& Kamal, 2012; Nahar, Hossain, \& Tazmeen, 2018). In short, it would be logical to conclude that research funds, grants, and scholarships in higher education not only improves the chances of students' success, but also assists in academic progression and professional development (Ashraf et al., 2016; Ganem \& Manasse, 2011).

\subsection{English as an Instructional Language}

Inadequate English language skills can hinder the quality of higher education and faculty engagement in professional development (Mazumder, 2014). Since English is not the primary language of Bangladesh, the students and the faculty are unable to properly utilize the internationally available information technology, research, and teaching tools (Asian Development Bank, 2017; Rabbani \& Chowdhury, 2014; M. M. Rahman, 2013). The solution is to make English the official language of Bangladesh like many other developing countries.

\subsection{Administrative Issues Hindering Faculty Engagement}

Administrative inefficiencies are not uncommon in universities because of weak administrative structures and practices (Islam, 2008). For example, universities are not able to employ a system through which the faculty is under any obligation to take classes. Another issue is the increase in student population in recent years. The recent overflow of students in universities have put considerable strain on administrative resources. It has become difficult for university administrations to manage a large number of students with a limited supply of faculty. This administrative problem is not only responsible for a detrimental quality of teaching but also is negatively corelated to faculty engagement in classes as well as other professional activities (Bidabadi, Isfahani, Rouhollahi, \& Khalili, 2016; F. Islam, 2008; Mohsin \& Kamal, 2012).

\subsection{Incentives and Pay}

Lack of incentives and inequities in pay are great demoralizers within any institutional setting, and it has been stated that inadequate budgetary support from the government and inappropriate implementation of the existing support due to a lack of good governance and inefficient utilization of allocated amounts has caused some of the challenges now affecting higher education in Bangladesh (Sarkar \& Hossain, 2016). In effect, because universities in the country are constrained because of low funding, there is little they can do regarding faculty engagement in professional development. Mostly, recurrent expenditures in these institutions are limited to the paying of salaries, without any meaningful development for academics. In such a scenario, the prospects of professional development are meagre (National Education Policy, 2010).

Another problem affecting higher education in Bangladesh is the lack of incentives. Research has noted that lack of incentives is one of the primary factors affecting the quality of education and faculty performance (World Bank, 2013). Incentives in higher education can include faculty education and training.

\subsection{Engaging Faculty in Professional Development Programs}

Faculty need to focus on the needs of their students, and for this to be achieved, the more sustained the professional development programs, the better the education outcomes. As a result, every educational system ought to have professional development programmes. In Bangladesh, higher education authorities have introduced a few professional development programs, but these programs have not been effective due to the lack of the program facilitators' knowledge, skills, and attitudes and the unavailability of modern training tools (Ahmed \& Iqbal, 2018; Hossain \& Khan, 2014).

Effective faculty engagement is essential for professional development. Faculty engagement in professional development can be linked to the ability of higher educational institutions to ensure that they move away from traditional teaching to modern ways of teaching. Bangladesh is striving to revamp its educational system from the traditional system to a more modernized system, such as incorporating andragogy as an effective teaching system as well as modernizing policies, programs, and practices (Hassan, 2016; Monem \& Baniamin, 2010). There is also 
a need to have an increased emphasis on seminars, conferences, and publications.

\subsection{Faculty Collaboration and Networking}

Faculty collaboration can be defined as the process of building valuable partnerships where faculty can bond over shared activities, which can draw on experiences and result in better teaching approaches. Unfortunately, faculty are mostly engaged with partisan politics and thus enclose themselves in silos based on their political support and ideology, which is a negative factor in maintaining effective collaboration and networking (Shiddike, 2016, 2019). Some benefits of effective networks could include long-term faculty collaboration, development of effective teaching strategies as a result of shared experiences, joint publications, collaborative applications for research funding, and collaboration with other public and private institutions (Islam, 2014). In addition to faculty collaboration and networking, there is also an immense need of international collaboration at the individual as well as university levels.

\subsection{Faculty Engagement and Partisan Politics}

Faculty engagement with partisan politics are likely to result in adverse outcomes. For example, partisan politics can result in a lack of discipline within the faculty of a university. Partisan politics have also been noted to pose great problems for both faculty and students in higher education because of constant interruptions (Ahmmed, 2013). This lack of discipline and interruptions can greatly affect faculty engagement largely because there is a lack of focus, and in some circumstances, getting available opportunities to pursue faculty professional development programmes may even be linked to political connections. Moreover, one problem that can be greatly associated with partisan politics is that unwieldy expansion of higher education institutions with little attention paid to quality may be perceived as an ill-conceived effort in pursuit of partisan political agendas (Asian Development Bank, 2015). As a case in point, while higher learning institutions have multiplied over the past few decades, this has often occurred without adequate considerations of quality and provision of opportunities. It is critical, then, that partisan politics is done away with in order to weed out potential strife or conflict that can affect or derail faculty engagement.

Therefore, it is important that the concerned authorities such as the UGC and the Ministry of Education help to free public universities from the clutches of party politics (Monem \& Baniamin, 2010). This can be done through the implementation of laws, policies or regulations that are meant to bar partisan politics in higher education institutions in order to foster a merit-based recruitment where only hard work and excellence are rewarded.

\subsection{Using Technology in the Classroom}

Quality education is an important element when considering or examining higher education in Bangladesh. The attainment of quality in classrooms is also dependent on the availability of information and information channels such as social media platforms and IT related teaching tools. The Asian Development Bank (2015) argued that Bangladesh requires network infrastructure and connectivity that can enhance information and communication technology (ICT) capacities, which will help in improving accreditation measures. These measures are currently inadequate or missing altogether in Bangladesh.

Technology and social media in the classroom can be viewed as a source of innovating the learning experiences of faculty and students (Tur \& Marin, 2015). The objective is to come up with newer strategies that can develop or enhance faculty's professional development such as through empowerment activities like broadening faculty collaborations and networking. In any case, the presence of technology and social media in classrooms can enhance the engagement of university faculty's professional development by providing opportunities for creating or developing connections through collaborative endeavours or by building effective networks.

\subsection{Other Deficiencies}

Bangladesh's education system is not in sync with the rest of the world regarding educational information and faculty engagement in professional development. Some aspects that are of concern in the country's educational system include the quality of teachers, the governance of higher learning institutions, and infrastructure. A lack of unified curriculum, a poor practice of quality standards, a lack of adequate facilities, and political interference are some of the educational deficiencies affecting Bangladesh (Prodhan, 2016). These factors can affect the professional development of faculty in various ways. For instance, a lack of unified curriculum will affect the ability of the country to develop functional professional development systems that provide a national outlook of the education system. Lack of facilities can also prevent teacher professional development because if there are insufficient training facilities to cater for professional development programmes. Moreover, the governance of higher learning institutions can also be a stumbling block, because there may be situations where faculty has no way of pursuing professional development because of constrained schedules. In effect, these factors are among the 
deficiencies that continue to prevent the higher learning institutions in Bangladesh from attaining efficiency and effectiveness. The same is true for individual faculty who are unable to develop professionally because of these obstacles.

\section{Current Trends and Research}

\subsection{Student-Centered Learning}

In Bangladesh, higher education is influenced by various trends and practices, particularly those relating to faculty engagement in professional development. One such trend is the student-centered approach in teaching and learning, which has been argued to provide more effectiveness regarding educational outcomes (Monem \& Baniamin, 2010; Park, 2012; Rabbani \& Chowdhury, 2014). Student-centered approaches are meant to put the needs of the learner first through active learning that promotes an interactive classroom environment. In professional development, faculty engagement is crucial for the realization of student-centered approaches and outcomes. In other words, higher learning institutions need to support faculty to help them reflect on their thinking and actions as they try to apply student-centered approaches in their lessons (Ahmed \& Iqbal, 2018; Ahmmed, 2013). The underlying argument, then, is that institutions of higher learning need to ensure student-centered learning strategies, and for that, they must develop mechanisms that promote faculty engagement in terms of professional development.

In Bangladesh, faculty engagement in professional development continues to raise some concerns. It has been observed that there needs to be reforms directed towards the availability of education and training programmes in Bangladesh as one way to promote the professional development of faculty (Park, 2012). When faculty would be able to access education and training to advance their knowledge and capacities, there would be better chances to engage professionally in the university.

\subsection{One-Way Teaching vs. Two-Way Teaching}

A common trend in higher education in Bangladesh is one-way teaching, which means that the teaching is mostly theoretical or book-oriented and ignores practical applications (Badruzzaman \& Mian, 2015). One-way teaching also tends to be uni-directional from the teacher to the student and not multi-directional or interactive. (Badruzzaman \& Mian, 2015; Hossain \& Khan, 2014; Islam, R. Islam, 2014; Monem \& Baniamin, 2010). Two-way teaching on the other hand, can develop analytical abilities among students. They become better professionals and conscientious citizens (Badruzzaman \& Mian, 2015; Ministry of Education, 2004).

\subsection{Teaching Resources}

Another problem is inadequate and out-of-date teaching resources. Higher education in Bangladesh is out of sync with the rest of the world. As a result, it is difficult to find latest editions of books or tap into the latest teaching methodologies or tools used in the rest of the world. Bangladesh is still struggling to modernize its higher education system to improve curriculums and standards (Khan, Rana, \& Haque, 2014; Monem \& Baniamin, 2010). Various factors have been identified that can assist in realizing professional development for any educational system, which can include better governance and management of educational institutions, improvement of recruitment conditions, implementing faculty quality assurance, and providing faculty training programmes, among others (Ahmed \& Iqbal, 2018; Asian Development Bank, 2017).

\subsection{Ethics and Values}

There is a sever deficiency of laws that can enforce ethics and values in higher education. For example, the University Grants Commission (UGC) has negligable legal authority to take any action regarding allegations of any kind against a given university (Ahmmed, 2013). While UGC is part of the hierarchy of higher education system, it is bogged down by political dependency and inadequate autonomy, particularly in enforcing educational standards and practices. Another weak link in the system is the issue of funding for higher education. The government's commitment to higher education funding, which might at least improve educational requirements such as quality, is low, as earlier observed (Ahmed \& Iqbal, 2018). This is also supported by the country's lack of institutional capacities to address the knowledge gap that exists between universities and the job market (Hassan, 2016).

In other words, higher education system of Bangladesh is unable to facilitate professional development of faculty. There is a need for the development of autonomous and powerful legal structure within the University Grants Commission and the Ministry of Education that can enforce faculty development and quality in higher education institutions without any political interference (Bidabadi et al., 2016; Karlsson \& Ryttberg, 2016).

\subsection{Partisan Politics}

Partisan politics is the main issue hindering the professional development of faculty in Bangladesh. Since 1971, 
Bangladeshi higher education institutions have been culturally developed in such a way that faculty is motivated to engage in partisan politics instead of professional development. Recruitment, promotions, and rewards are based on the political inclinations of the faculty and interest groups prevalent in the respective educational institutions. This results in the creation of an organizational culture where everything revolves around power and politics. Professionalism, a strive for knowledge, a motivation to increase the quality of teaching, an obligation to produce research papers, and an interest to participate in seminars and conferences etc. take a back seat. Such a bleak situation raises a question that what would happen if an ethical code of conduct were developed that would prevent and/or intervene in instances of unethical conduct such as engagement in partisan politics (Bar-Tal \& Harel, 2002; Shiddike, 2016). Partisan politics can adversely affect the goals and objectives of faculty engagement in professional development in the sense that it robs the process of integrity and achievement is not based on merit (Campbell, 2008; Nuland \& Khandelwal, 2006; Shiddike, 2016, 2019). As a result, there is a need to foster the development and implementation of ethical standards, policies, laws, and practices within the education system if goals such as faculty engagement in professional development are to be achieved.

\subsection{Faculty Attitudes and Cultural Issues}

Faculty engagement is critical for the development of educational outcomes, just as are prevailing cultural issues. A properly engaged faculty tends to show higher levels of attachment to the profession (Barman \& Ray, 2011). The idea is that highly engaged faculty can develop and practice more positive attitudes as compared to a disengaged one (Lohman, 2006). Positive attitudes towards teaching are dependent on the working conditions put in place towards developing a functioning educational system, and management initiatives such as the provision of incentives or better pay to improve the chances of faculty having positive attitudes because the faculty will be positively motivated (Anwaruddin, 2015). Positive attitudes can also be attained by developing mechanisms that are centered on andragogy more than on pedagogy (Smith, Sheppard, D. W. Johnson, \& R. T. Johnson, 2005). The idea is that faculty will feel more confident in their practices if they can properly use their skills and expertise when addressing challenges within the educational system.

Cultural issues can also effect positive attitudes (Rogers, 2014), and can be understood in two ways. First, prevailing organizational cultures must transform to fit the current demands of education as a means of addressing professional development requirements in Bangladesh. The objective is to create or develop organizational or institutional policies that can assist in developing the strategies for and outcomes of professional development. The second understanding of cultural issues can be seen through the lens of national culture, where certain values influence the overall educational system of the country. Therefore, national or cultural values may either promote or hinder faculty engagement in professional development, depending on the types of national values.

\section{Summary and Conclusion}

Bangladesh is struggling with its education sector, even decades after independence. The higher educational institutions are trying to modernise the system but are facing unprecedented challenges in the areas like advancements in technology and a change in organizational culture. While education has improved to some extent, since the country has increased its universities tenfold, there are still concerns that some important factors such as faculty engagement in professional development are either under-addressed or not being addressed at all. Such circumstances have necessitated the examination of key issues affecting higher education in Bangladesh.

It is imperative to note that professional development is critical for sustainable development of higher education sector. Professional development can be linked to quality outcomes of education, which should be the goal of every educational systems around the world. Further, Bangladesh faces various issues that continue to impede its ability to offer improved engagement in professional development, such as a lack of resources and a lack of relevant education and training opportunities for faculty. Given these factors, it is necessary to come up with strategies to remedy the situation. Such strategies can be realized by examining the current state of education around the world and comparing it with Bangladesh in order to determine which areas need urgent attention.

This paper analyses the key issues and practices in faculty engagement in professional development in the higher education of Bangladesh. The paper begins with an overview of the country of Bangladesh and its higher education institutions, with an overview of higher education faculty engagement in professional development. Then, the paper sheds light on the significance of faculty engagement in professional development. The paper also highlights the problems that Bangladesh faces and prospective solutions. For example, the numbers of adult students in higher education institutions are increasing every year, and so Bangladesh needs to address this issue. At the end, the paper reviews the issues with the current trends and practices in higher education from 2000 to the present and proposes solutions. 
Professional development is critical for successful faculty engagement. It is essential that the solutions devised for faculty engagement are holistic in order to ensure that they address the short and long-term concerns regarding professional development. Countries such as Bangladesh with struggling educational systems need to work with stakeholders such as lawmakers, administrators, and faculty themselves to come up with solutions that not only promote effectiveness in professional development outcomes but are also sustainable in the long run.

\section{References}

Ahmed, I., \& Iqbal, I. (2018). University of Dhaka: In Search for Excellence Issues and Policy Recommendations. Retrieved from Dhaka: http://fes-bangladesh.org/files/daten/publications/University\%20of\%20Dhaka.pdf

Ahmmed, M. M. (2013). Higher education in public universities in Bangladesh. Journal of Management and Science, 3(2). Retrieved from http://citeseerx.ist.psu.edu/viewdoc/download?doi=10.1.1.683.9059\& rep $=$ rep $1 \&$ type $=$ pdf

Akareem, H., Salilul, \& Hossain, S. S. (2016). Determinants of education quality: what makes students' perception different. Open Review of Educational Research, 3(1), 52-67. https://doi.org/10.1080/23265507.2016.1155167

Anwaruddin, S. M. (2015). Teachers engagement with educational research: Toward a conceptual framework for locally-based interpretive comminities. Education policy analysis archives, 23(40), 01-22. https://doi.org/10.14507/epaa.v23.1776

Ashraf, M. A., Ibrahim, Y., \& Joarder, M. H. R. (2009). Quality education management at private universities in Bangladesh: An exploratory study. Jurnal Pendidk den Pendidikan, 24, 17-32.

Ashraf, M. A., Osman, A. Z. R., \& Ratan, S. R. A. (2016). Determinants of quality education in private universities from student perspectives: A case study in Bangladesh. Quality Assurance in Eduation, 24(1), 123-138. https://doi.org/10.1108/QAE-09-2013-0040

Asian Development Bank. (2017). Innovative strategies in higher education for accelerated human resource development in South Asia Bangladesh. Retrieved from Manila, Phillippines: https://www.adb.org/publications/innovative-strategies-higher-education-bangladesh

Badruzzaman, M., \& Mian, M. N. (2015). Right to education in Bangladesh: An appraisal for constitutional guarantee. Journal of Studies in Social Sciences, 13(1), 1-34.

Bangladesh Bureau of Educational Information and Statistics (BANBEIS). (2017). Bangladesh Education Statistics. $\quad$ Retrieved from http://lib.banbeis.gov.bd/BANBEIS_PDF/Bangledesh\%20Education\%20Statistics\%202016.pdf

Bar-Tal, D., \& Harel, A. S. (2002). Teachers as agents of political influence in the Israeli high schools. Teaching and Teacher Education, 18, 121-134. https://doi.org/10.1016/s0742-051x(01)00054-3

Barman, A., \& Ray, M. S. (2011). Faculty engagement in higher educational institution: A proposed model. Romanian Journal for Multidimensional Education. Retrieved from https://www.researchgate.net/publication/215713725_1_Faculty_Engagement_in_Higher_Educational_Insti tution_-A_proposed_model/download

Behari-Leak, K. (2017). New academics, new higher education contexts: A critical perspective on professional $\begin{array}{llll}\text { development. Teaching in Higher } & \text { Education, 22(5), }\end{array}$ https://doi.org/10.1080/13562517.2016.1273215

Beine, M., Docquier, F., \& Rapoport, H. (2008). Brain drain and human capital formation in developing countries: Winners and losers. The Economic Journal, 118, 631-652. https://doi.org/10.1111/j.1468-0297.2008.02135.x

Bidabadi, N. S., Isfahani, A. R. N., Rouhollahi, A., \& Khalili, R. (2016). Effective teaching methods in higher education: requirements and barriers. Journal of Advances in Medical Education \& Professionalism, 4(4), $170-178$.

Broad, K., \& Evans, M. (2006). A review of literature on professional development content and delivery modes for experienced teachers. Retrieved from Ontario Institute for Studies in Education:

Campbell, E. (2008). The ethics of teaching as a moral profession. The Ontario Institute for Studies in Education, Unniversity of Toronto, 38(4), 357-385. https://doi.org/10.1111/j.1467-873X.2008.00414.x

Capps, D. K., Crawford, B. A., \& Constas, M. A. (2012). A review of empirical literature on inquiry professional development: Alignment with best practices and a critique of the findings. Journal of science teacher 
education, 23(3), 291-318. https://doi.org/10.1007/s10972-012-9275-2

Carini, R. M., Kuh, G. D., \& Kleint, S. P. (2006). Student engagement and student learning: Testing the linkages. Research in Higher Education, 47(1), 01-32. https://doi.org/10.1007/s11162-005-8150-9

Ganem, N. M., \& Manasse, M. (2011). The relationship between scholarships and student success: An art and design case study. Educational Research International, 1-8. https://doi.org/10.1155/2011/743120

Hanushek, E., A. (2016). Will more higher education improve economic growth? Oxford Review of Economic Policy, 32(4), 538-552. https://doi.org/10.1093/oxrep/grw025

Harper, S., R., \& Quaye, S., John. (2015). Student engagement in higher education: Theoritical perspectives and practical approached for diverse populations (2nd ed.). New York, NY: Routhledge.

Hassan, M. M. S. (2016). Revamping higher education in Bangladesh. Paper presented at the Proceedings of 53rd ISERD Internatiomnal Conference, Zurich, Switzerland.

Hossain, M. M., \& Khan, A. M. (2014). Higher education reform in Bangladesh: An analysis. Mediterranean Journal of Social Sciences, 5(9), 423-427. https://doi.org/10.5901/mjss.2014.v5n9p423

Islam, F. (2008). Some issues of higher education in Bangladesh: Analysis of demand, problems and trends. Prime University Journal, 2(2), 1-9.

Islam, R. (2014). Higher education in Bangladesh: diversity, quality and accessibility. Paper presented at the First National Education Conference on Whither Policy Reform in Education: Lessons and Challenges, Bangladesh.

Kapur, S. (2015). Andragogy: The adult learning theory. Indian Journal of Adult Education, 76(2), 40-50.

Karlsson, S., \& Ryttberg, M. (2016). Those who walk the talk: The role of administrative professionals in transforming universities into strategic actors. Nordic Journal of Studies in Educational Policy, 2(3). https://doi.org/10.3402/nstep.v2.31537

Kelly, J. (2017). Professional learning and adult learning theory: A connection. Northwest Journal of Teacher Education, 12(2). https://doi.org/10.15760/nwjte.2017.12.2.4

Khan, M. N., Rana, E. A., \& Haque, M. R. (2014). Reforming the education system in Bangladesh: Reckoning a knowledge-based society. World Journal of Education, 4(4), 1-11. https://doi.org/10.5430/wje.v4n4p1

Koellner, K., \& Jacobs, J. (2015). Distinguishing models of professional development: The case of an adaptive model's impact on teachers' knowledge, instruction, and student achievement. Journal of Teacher Education, 66(1), 51-67. https://doi.org/10.1177/0022487114549599

Kuh, G. D. (2009). The national survey of student engagement: Conceptual and empirical foundations. Wiley Inter-Science, (141), 05-20. https://doi.org/10.1002/ir.283

Lamagna, C. (2006). Quality assurance in tertiary education-Bangladesh experience. Paper presented at the World Bank Learning Seminar, CIEP, France.

Lohman, M. C. (2006). Factors influencing teachers' engagement in informal learning activities. Journal of workplace learning, 18(3), 141-156. https://doi.org/10.1108/13665620610654577

Mahmud, M., Mozumder, G. N., Shahana, S., \& Islam, S. (2018). Final round satisfaction survey of higher education quality enhancement project (HEQEP). Retrieved from http://bidslink.bids.org.bd/bidsorgbd/completed_research/HEQEP_FRSS\%20Final\%20Report\%20for\%20W ebsite.pdf

Mazumder, Q. H. (2014). Analysis of Quality in Public and Private Universities in Bangladesh and USA. International Journal of Evaluation and Research in Education, 3(2), 99-108.

Merriam, S. B. (2001). Andragogy and self-directed learning: Pillars of adult learning theory. New Directions for Adult \& Continuing Education, 89, 3-13. https://doi.org/10.1002/ace.3

Merriam, S. B. (2008). Adult learning theory for the twenty-first century. New Directions for Adult \& Continuing Education, 119, 93-98. https://doi.org/10.1002/ace.309

Ministry of Education. (2004). Development of education: National report of Bangladesh. Dhaka, Bangladesh

Mohsin, M., \& Kamal, M. A. (2012). Managing quality higher eduation in Bangladesh: Lessons from the Singaporean and Malaysian strategies and reforms. International Journal of business and management, 7(20), 59-70. https://doi.org/10.5539/ijbm.v7n20p59 
Monem, M., \& Baniamin, H. M. (2010). Higher Education in Bangladesh: Status, Issues and Prospects. Pakistan Journal of Social Sciences (PJSS), 30(2), 293-305.

Nahar, N., Hossain, S., \& Tazmeen, A. (2018). Establishment of an effective institutional quality assurance cell in a higher education institution of Bangladesh: Case study North South University. Paper presented at the First International Conference on Quality Assurance in Higher Education, North South University, Dhaka, Bangladesh.

National Education Policy. (2010). National education policy. Dhaka, Bangladesh: Government of the Peoples Republic of Bangladesh

Nelson, M. (2014). Engaging adult learners in professional development environments. Grand Canyon University. Retrieved from https://www.researchgate.net/publication/318349551_Engaging_Adult_Learners_in_ Professional_Development_Environments/download

Nuland, S. v., \& Khandelwal, B. P. (2006). Ethics in education: The role of teacher codes Canada and South Asia. Retrieved from Paris: https://files.eric.ed.gov/fulltext/ED495400.pdf

Park, J. T. R. (2012). Teacher change in Bangladesh: A study of teachers adapting and implementing active learning into their practice. (Doctor of Philosophy Paper).

Pianta, R. C., Hamre, B. K., \& Allen, J. P. (2012). Teacher-student relationships and engagement: Conceptualizing, measuring, and improving the capacity of classroom interactions. In Hand book of research on student engagement (pp. 365-386).

Prodhan, M. (2016). The educational system in Bangladesh and scope for improvement. Journal of International Social Issues, 4(1), 11-23.

Rabbani, G., \& Chowdhury, S. (2014). Quality of higher education in Bangladesh: Governance framework and quality issues. Beykent University Journal of Social Sciences, 7(1), 78-91.

Rahman, A. A., \& Shiddike, M. O. (2019). Agendas for future training transfer research: Pakistan's persepctive. Developing Country Studies, 9(4), 39-48. https://doi.org/10.7176/DCS/9-4-06

Rahman, M. M. (2013). Quality higher education and students' perception: A study on private universities of Bangladesh. Global Dislosure of Eonomices and Business, 2(1), 09-19.

Rogers, E. (2014). Influencing teacher engagement in informal interaction leading to professional learning: A theoretical model (pp. 1-293).

Roorda, D. L., Koomen, H. M. Y., Spilt, J. L., \& Oort, F. J. (2011). The influence of affective teacher-student relationships on students' school engagement and achievement: A meta-analysis approach. Review of Educational Research, 81(40), 493-529. https://doi.org/10.3102/0034654311421793

Sarker, S. H., \& Hossain, S. Z. (2016). Budgetary challenges of higher education: Evidence from Bangladesh. Journal of education and practice, 7(12), 32-41.

Sarker, S. H., Rana, S., \& Zitu, R. A. (2013). Challenges of quality education in Bangladesh: A study on public universities. Journal of education and practice, 4(8), 151-161.

Shiddike, M. O. (2016). Teacher engagement in national partisan politics: A Bangladesh case study (Master dissertation). University of Regina, Regina, Canada.

Shiddike, M. O. (2019). A case study of teacher engagement in partisan politics and it's influences on students learning and classroom practices: Perspective on Bangladesh. World Journal of Education, 9(3), 22-29. https://doi.org/10.5430/wje.v9n3p22

Shuva, N., Z., \& Taisir, R. (2016). Faculty members' perceptions and use of open access journals: Bangladesh perspective. International Federation of Library Associations and Instructions, 42(1), 36-48. https://doi.org/10.1177/0340035216628879

Siegfried, J. J., Sanderson, A. R., \& McHenry, P. (2007). The economic impact of colleges and universities. Economics of Education Review, 26, 546-558.

Smith, K. A., Sheppard, S. D., Johnson, D. W., \& Johnson, R. T. (2005). Pedagogies of engagement: Classroom based practices. Journal of Engineering Education, 01-15. https://doi.org/10.1002/j.2168-9830.2005.tb00831.x

System Approach for Better Education Results (SABER). (2017). Bangladesh tertiary education. Retrieved from 
http://documents.worldbank.org/curated/en/262771505984385656/pdf/119786-BRI-PUBLIC-SABER-Terti ary-Bangladesh-CR2017-preliminary.pdf

Trotter, Y. D. (2006). Adult learning theories: Impacting professional development programs. Delta Kappa Gamma Bulletin, 72(2), 8-13.

Tur, G., \& Marin, V. I. (2015). Enhancing learning with the social media: Student teachers' perspections on Twitter in a debate activity. New Approached in Educational Research, 4(1), 46-53. https://doi.org/10.7821/naer.2015.1.102

University Grants Commission (UGC). (2018). Annual Report-2017. Dhaka, Bangladesh. Retrieved from http://www.ugc.gov.bd/

World Bank. (2013). Bangladesh Education Sector Review. Retrieved from Dhaka, Bangladesh: https://openknowledge.worldbank.org/bitstream/handle/10986/16768/806130ESW0BD0E00Box379859B0 OPUBLIC0.pdf

\section{Copyrights}

Copyright for this article is retained by the author(s), with first publication rights granted to the journal.

This is an open-access article distributed under the terms and conditions of the Creative Commons Attribution license (http://creativecommons.org/licenses/by/4.0/). 